\title{
Environmental Health Risk Assessment of Toluene Exposure
}

\author{
Fea Firdani ${ }^{1}$, I Made Djaja ${ }^{2}$, Emma Hermawati ${ }^{2}$ \\ \{feafirdani@ph.unand.ac.id ${ }^{1}$,imddjaja@ui.ac.id²,ema_her@ui.ac.id² ${ }^{2}$, \\ Department of Occupational and Environmental Health, Andalas University, Padang, Indonesia ${ }^{1}$ \\ Department of Environmental Health, Universitas Indonesia, Depok, Indonesia ${ }^{2}$
}

\begin{abstract}
Toluene is one of the aromatic hydrocarbon compounds used as a solvent. Exposure toluene can pose health risks for workers. Environmental health risk assessment was conducted to determine the effect of toluene exposure. This research was conducted on 40 workers from 3 footwear industries in West Java, Indonesia, in 2017. The mean concentration of toluene in the workplace air is $5.6 \mathrm{mg} / \mathrm{m}^{3}$. Anthropometric data showed 55 kilograms as the weighted average of footwear's workers. Activity pattern includes an average of 8 hours a day as time exposure, 312 days a year as a frequency of exposure, and 11 years as working time in the footwear industry. The risk quotient for the population is still below the reference dose of IRIS. Suggestion for the safe concentration limit of toluene during 8 hours exposure is $16.6 \mathrm{mg} / \mathrm{m} 3$. Workers should use personal protective equipment such as masks accompanied by toluene absorbers to avoid the risk of exposure.
\end{abstract}

Keywords: toluene, risk quotient, footwear's workers.

\section{Introduction}

The National Institute of Occupational Safety and Health reports 9.8 million workers in the United States, and 400 thousand workers in Denmark are exposed to organic solvents. Benzene, toluene, xylene, and styrene are aromatic organic solvents that are frequently used in industry.[1] Toluene is one of the aromatic hydrocarbon compounds, mostly toluene, in the form of a mixture of benzene, toluene, and xylene. In the process of making footwear, chemicals that can interfere with the health of workers are the use of glue as a solvent. Indoor air can contain higher toluene in a place that uses products such as paint thinners, solvents, or tobacco products. In the workplace, the risk of exposure to toluene increases in workers who use toluene or produce toluene-containing products. Workers can be exposed to toluene through inhalation of chemical vapors, absorbed through the skin when the glue is used by hand, can also be swallowed when eating, smoking, or drinking at work[2].

Adhesives and solvents that are often used in the footwear industry contain hazardous materials, such as toluene, methyl ethyl ketone, and acetone. Research by Pakasi et al. in 2006 on the content of solvents in adhesives used in the informal sector footwear industry in Cinemas Bogor, the results of the extraction of adhesives showed the dominant toluene content and benzene still present in all brands of adhesives used in this industry. Toluene is widely used as a substitute for more toxic benzene solvents. So that continued exposure can be bad for the health of the workforce[3]. Chronic toluene exposure through chronic inhalation can cause pressure on 
the central nervous system. Symptoms include drowsiness, ataxia (loss of ability to control body movements), tremors (vibrating body parts), cerebral atrophy, nystagmus (involuntary movements of the eyeball) and impaired speech, hearing and seeing. Besides irritation of respiratory and eye tracts, sore throat, headaches, and sleep difficulties have also been found in several studies[1].

Ciomas Bogor is one of the regions in West Java, which produces a lot of footwear. In the process of footwear production in Ciomas using glue containing toluene solvent. Previous studies it was found that the most dominant toluene content in the glue used. Therefore environmental health risk assessment was conducted to determine the effect of toluene exposure. Health risk assessment is estimating health problems that may arise and the magnitude of the consequences caused at a certain time. Health risk assessment is part of the risk analysis framework, which consists of 3 parts, that are risk assessment, risk management, and risk communication. The purpose of risk analysis is to assess and estimate human health risks caused by exposure to environmental hazards. Analysis can be done on environmental exposure that has occurred with adverse effects that have or have not occurred. The results of the risk analysis are very useful, especially for decision-makers to manage health risk control that exists or may arise in the future and are useful as a basis for conducting risk communication to all relevant sectors[4].

\section{Materials and methods}

This research was conducted on 40 workers from 3 footwear industries in West Java, Indonesia, in 2017. Environmental health risk assessment methods is one method of studying the effects of the environment on health. The first step in risk analysis is potential hazard identification by measuring the amount of toluene concentration in the workplace air. They are performed using the NIOSH 1501 measurement method and using the Gas Chromatography technique. The second is exposure assessment by calculating the amount of toluene intake that enters the body. The third is response dose assessment, not direct analysis but based on the Integrated Risk Information System (IRIS). The fourth steps were risk characterization by calculating the estimated risk level and the last steps risk management to determine the safe limit of toluene concentration.

\section{Result}

\subsection{Hazard Identification}

Hazard identification by measuring the amount of agent (toluene) concentration in the environment in which the agent is located. The concentration of toluene in the workplace was measured as many as 9 points in 3 footwear industries. Each footwear industry was taken 3 points of the air measurement sample. The results of measurements of toluene concentrations in air are explained in table 1 . 
Table 1. Results of measurements of toluene concentrations in the workplace

\begin{tabular}{cc}
\hline Sampling Points & Toluene Concentration $\left.\mathbf{( m g} / \mathbf{m}^{\mathbf{3}}\right)$ \\
\hline 1 & 0.19 \\
2 & 0.34 \\
3 & 0.14 \\
4 & 0.00 \\
5 & 2.28 \\
6 & 4.57 \\
7 & 1.19 \\
8 & 1.23 \\
9 & 22.72 \\
\hline
\end{tabular}

The average concentration of toluene in the workplace was $5.60 \mathrm{mg} / \mathrm{m} 3$, with the highest concentration of $22.72 \mathrm{mg} / \mathrm{m} 3$. The results of measurements of toluene concentrations in the work environment of the footwear industry; all measurement points indicate the concentration of toluene in the workplace is still below the set threshold value.

\subsection{Exposure Assessment}

An exposure assessment is measuring or calculating the intake of a risk agent. Intake is the amount of intake an individual receives per body weight per day. To calculate the intake used the formula [5]:

$$
I=\frac{C x R \times \text { te } x f e \times D t}{W b x \operatorname{tavg}}
$$

Note :

I : Intake the number of risk agents received by individuals per unit of body weight Each day $\left(\mathrm{m}^{3} / \mathrm{kg} /\right.$ day $)$

$\mathrm{C}$ : Concentration of risk agent, toluene in air $\left(\mathrm{mg} / \mathrm{m}^{3}\right)$

$\mathrm{R}$ : Rate of intake $\left(\mathrm{m}^{3} /\right.$ hour $)$

Te : Exposure time per day (hour/day) for inhalation

$\mathrm{Fe} \quad$ : Frequency of annual exposure (day/year)

Dt : Duration of exposure (year) realtime or projected 30 years

$\mathrm{Wb}$ : Weight of body $(\mathrm{kg})$

Tavg : Periods of average time, 30 years x 365 days/years (non-carcinogenic)

The calculation of intake using Microsoft excel from the primary data that has been collected in the field. The results of the calculation directly described with the following values. The results of field studies found that the average concentration (C) of toluene in the workplace is $5.60 \mathrm{mg} / \mathrm{m} 3$, Inhalation rate $(\mathrm{R})$, or the volume of air entering every hour into the body by taking the default value for the adult inhalation rate $0.83 \mathrm{~m} 3 /$ hour. Time of exposure (te) is the duration of exposure each day, the average length of work each day is 8 hours/day. The frequency of exposure (fe) is the number of days of annual exposure, which is 312 days/year. Duration of time (Dt) the number of years of exposure lasts, with an average of 11 years, projected to be 30 years. Weight of body $(\mathrm{Wb})$ is the average body weight of the workers sampled from this study that is $55 \mathrm{~kg}$, and The time average (tavg) or average time for noncarcinogenic effects is 30 years x 365 days/year. Intake value calculated : 


$$
I=\frac{5.60 \mathrm{mg} / \mathrm{m}^{3} \times 0.83 \mathrm{~m}^{3} / \text { hour } \times 8 \text { hours } / \text { day } \times 312 \text { hours/year } \times 11 \text { years }}{55 \mathrm{~kg} \times 30 \text { years } \times 365 \text { days } / \text { year }}
$$

The result of the calculation intake of toluene exposure in the workplace is $0.21 \mathrm{~m}^{3} / \mathrm{kg} / \mathrm{day}$.

\subsection{Response Dose Assessment}

Reference Concentration (RfC) for the inhalation pathway is to estimate the dose of exposure, which is not expected to cause adverse health effects even though the exposure continues throughout life. The dose of inhalation intake of toluene is $5 \mathrm{mg} / \mathrm{m}^{3}[6]$.

\subsection{Risk Characterization}

Risk characterization is staged for estimating an adverse risk that can occur in humans as a result of exposure expressed by Risk Quotient (RQ). These estimates can be done by estimating risk, i.e., quantification of the probability of occurrence of risk based on data sourced from hazard identification values, effect analysis, and exposure assessment. To risk characterization, human exposure (intake) is compared with reference concentration. The risk characterization obtained by calculating the estimated risk level with the RQ calculation equation [7] :

$$
R Q=\frac{\text { Intake }}{R f C}
$$

The results of the calculation of RQ, it is known that the RQ value $<1(0.14)$, shows that the exposure is below the reference dose so that workers exposed to toluene have a lower risk of getting adverse effects on health. Meanwhile, the individual risk quotient is five workers above the reference dose $(\mathrm{RQ}>1)$ and 35 workers below the reference dose $(\mathrm{RQ}<1)$.

\subsection{Risk Management}

Risk management is carried out to control risk through the determination of safe concentration limits for workers. The safe limit for toluene concentration is calculated using exposure time (te) data, frequency of exposure (fe), inhalation rate (R) using a default value of $0.83 \mathrm{~m} 3 /$ hour, duration of exposure time (Dt) and the average period of exposure (tavg) ) which will be known from the results of data collection in the field. The equation to calculate the concentration is:

$$
C=\frac{R f C \times W b \times \operatorname{tavg}}{R \times t e \times f e \times D t}
$$

The safe limits toluene concentration for footwear industry workers in Ciomas, West Java is under $16.6 \mathrm{mg} / \mathrm{m}^{3}$. 


\section{Discussion}

In the ATSDR (2000), it was explained that one of the industries potentially exposed to toluene was in the footwear industry. Used as a solvent for the adhesive used in glue. From the results of measurements of 9 toluene concentration points in the footwear industry workplace in Ciomas, West Java, all measurement points show the toluene concentration in the workplace is still below the threshold limit values at $188.43 \mathrm{mg} / \mathrm{m} 3$ based on the Minister of Manpower and Transmigration Regulation No. PER.13/MEN/X/2011.[1][8]

The results of the measurement of the average concentration of toluene in the workplace air of $5.60 \mathrm{mg} / \mathrm{m}^{3}$ have been more than the specified response dose of $5 \mathrm{mg} / \mathrm{m}^{3}$. However, if compared with the threshold limit values (TLV), the average concentration of toluene in the workplace is below the threshold. According to the 1985 IPCS, the relationship between acute dose-response of toluene exposure explained that the concentration of toluene at $9.4 \mathrm{mg} / \mathrm{m} 3$ had a response only to the threshold of pungent odor. But when compared with the determination of the toluene threshold limit values (TLV) $188 \mathrm{mg} / \mathrm{m} 3$, the concentration of toluene in the workshop is still within safe limits.[6][4]

In contrast to research at the Shoe Manufacturing Workshops in East Tehran that toluene in the workplace air has higher exposure than the TLV set by ACGIH (20 ppm or $\left.75.37 \mathrm{mg} / \mathrm{m}^{3}\right)$. As well as Chinese and Mexican shoemakers also have higher toluene exposure than the specified TLV.[9] [10][11]

Another source of toluene is cigarette smoke. Based on field observations, most workers smoke in the room while working. The results obtained can be seen that $65 \%$ of workers smoke. Smoking can increase health risks from toluene exposure. The body's response to toxic chemicals depends on the length and amount of exposure. Short-term exposure with low chemical concentrations may not have a significant effect, but if the exposure period is long, then the chemical can cause hazards.[4]

Anthropometric data measured in this study is body weight. The average body weight of workers is $55 \mathrm{~kg}$, with a range of $35 \mathrm{~kg}-93 \mathrm{~kg}$. Weight is one factor that affects the amount of intake that enters the body of the worker through inhalation. The bodyweight used in the determination of the inhalation rate is the average American body weight of $70 \mathrm{~kg}$ (for adults). It is because no research can be a provision for the average body weight of Asians. The inhalation rate uses the default value of the US EPA, $1991\left(20 \mathrm{~m}^{3} /\right.$ day or $0.83 \mathrm{~m}^{3} /$ hour) [6].

Activity pattern data includes the time of exposure (te), frequency of exposure (fe), and duration of exposure (Dt). For the time of exposure, the results of the study indicate that the working time of workers in the footwear industry in one day, which is an average of 8 hours. The time of exposure to footwear industry workers is also related to the length of time workers are exposed to toluene. Although the concentration of toluene is below the threshold limit values (TLV), if inhaled continuously, it can affect the amount of intake of these hazardous substances.

Frequency of Exposure (fe) is ts the number of working days in a week. Based on the results of interviews, it is known that workers work six days a week. Based on the results of the analysis shows that the average footwear industry workers work for 312 days in one year. The duration of exposure (Dt) in this study is the length of time workers work in units of years in the Ciomas footwear industry in West Java. The results of the analysis show that the duration of this exposure is quite large, from 1 year to 30 years working with an average of 11 years.

The level of risk (RQ) of individuals, obtained that the RQ value of more than one is found in the gluing section of 5 people (12.5\%). It is due to the highest concentration of toluene in this section compared to other parts, which is $22.72 \mathrm{mg} / \mathrm{m} 3$. The use of glue in this section is quite a lot. In this section, the task is to unite the top and bottom of the shoe. They need a lot of glue. 
All workers also did not use personal protective equipment, especially masks, so that the strongsmelling glue vapors were inhaled immediately. When asked if they were not bothered by the smell, they said they were accustomed to such a smell.

Habits that exacerbate health risks are smoking in the workspace. In addition, because of the hot room temperature, they also have the habit of working without clothes. It can cause the toluene vapors to be absorbed into the worker's body through the skin.

The level of risk (RQ) of individuals, obtained that the RQ value of more than one is found in the gluing section of 5 people (12.5\%). It is due to the highest concentration of toluene in this section compared to other parts, which is $22.72 \mathrm{mg} / \mathrm{m} 3$. The use of glue in this section is quite a lot. In this section, the task is to unite the top and bottom of the shoe. They need a lot of glue. All workers also did not use personal protective equipment, especially masks, so that the strongsmelling glue vapors were inhaled immediately. When asked if they were not bothered by the smell, they said they were accustomed to such a smell.

Habits that exacerbate health risks are smoking in the workspace. In addition, because of the hot room temperature, they also have the habit of working without clothes. It can cause the toluene vapors to be absorbed into the worker's body through the skin.

From the calculation of safe concentration limits for workers, if they work in accordance with the provisions of the applicable working hours of 8 hours a day and six days a week and using anthropometric data of footwear industry workers in Ciomas West Java. It is obtained that the safe concentration limit for 25 years is not necessarily carried out risk control is not more than $16.6 \mathrm{mg} / \mathrm{m}^{3}$. These results are not the same as the toluene threshold limit value (TLV) set in Indonesia, which is $188 \mathrm{mg} / \mathrm{m} 3$. The determination of TLV may be only based on ambient air concentrations. There are no studies in Indonesia that can determine how large the dose of the toluene response is safe, especially for Indonesian workers.

\section{Conclusion}

The mean concentration of toluene in the workplace air is $5.6 \mathrm{mg} / \mathrm{m}^{3}$, with the highest concentration of $22.7 \mathrm{mg} / \mathrm{m}^{3}$. Anthropometric data showed 55 kilograms as the weighted average of footwear's workers. Activity pattern including the average of 8 hours a day as time exposure, 312 days a year as a frequency of exposure, and 11 years as working time in the footwear industry. The concentration of toluene in the workplace has not caused health risks for workers. The risk quotient for the population is still below the reference dose of IRIS $(<1)$. while the individual risk quotient is five workers above the reference dose and 35 workers below the reference dose. Recommended that workers use personal protective equipment such as masks accompanied by toluene absorbers to avoid the risk of exposure. The safe concentration limit for 25 years is not necessarily carried out risk control for workers in the footwear industry in Ciomas, West Java is not more than $16.6 \mathrm{mg} / \mathrm{m}^{3}$.

\section{References}

[1] Agency for Toxic Substances and Disease Registry, "Toxicological Profile for Toluena," Georgia, 2000.

[2] Agency for Toxic Substances and Disease Registry, "Draft Toxicological Profile For Toluene," Georgia, 2015. 
[3] International Labour Organizations, "Pekerja Anak di Industri Sepatu Informal di Jawa Barat (Sebuah Kajian Cepat)," Jakarta, 2004.

[4] International Programme on Chemical Safety (IPCS), “Air Quality Guidelines Toluene," Geneva, 2000.

[5] J. . Louvar dan B. D. Louvar, Health, and Environmental Risk Analysis. New Jersey, 1998.

[6] Integrated Risk Information System, "Toxicological Review of Toluena," Washington DC, 2005.

[7] Kolluru R et al., Risk Assessment And Management Handbook. New York, 1996.

[8] Peraturan Menteri Tenaga Kerja Dan Transmigrasi Nomor PER.13/MEN/X/2011, "Nilai Ambang Batas Faktor Fisika dan Faktor Kimia di Tempat Kerja."

[9] S. M. A. M. Mansour R. Azari, Vajihe Hosseini, Mohammad Javad Jafari, Hamid Soori, Parisa Asadi, "Evaluation of Occupational Exposure of Shoe Makers to Benzene and Toluene Compounds in Shoe Manufacturing Workshops in East Tehran," Tanaffos, vol. 11, no. 4, hal. 43-49, 2012.

[10] K. W. A. L. González-Yebra, C. Kornhauser, G. Barbosa-Sabanero, E. L. Pérez-Luque, "Exposure to organic solvents and cytogenetic damage in exfoliated cells of the buccal mucosa from shoe workers," Int. Arch. Occup. Environ. Health, vol. 82, no. 3, hal. 373-380, 2009.

[11] R. Vermeulen et al., "Detailed Exposure Assessment for a Molecular Epidemiology Study of Benzene in Two Shoe Factories in China," Ann. Occup. Hyg., vol. 48, no. 2, hal. 105-116, 2004. 